\title{
介護保険施設に入所する認知症高齢者の BPSD に及ぼす生活の質（QOL）の影響
}

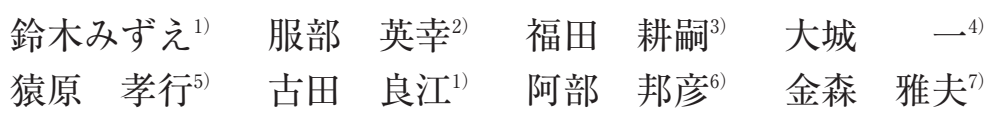

\section{要約}

目的：本研究の目的は介護保険施設に打ける認知症高齢者の認知症の行動・心理症状（BPSD）に及ぼす生活の 質 (QOL) の影響を明らかにすることである. 方法：介護保険施設に入所する認知症高齢者の ADL (Katz), Minimental State Examination(MMSE), Neuropsychiatric Inventory(NPI), Quality of life inventory for elderly with dementia（QOLD）を評価した．結果：対象者は男性 121 名，女性 396 名の合計 517 名，介護老人福祉施設 200 名 $(38.7 \%)$, 介護療養型医療施設 91 名 $(17.6 \%)$, 介護老人保健施設 226 名 $(43.7 \%)$ で, 平均年齢 $85.18 \pm 7.13$ 歳であった. NPI に関しては, 介護療養型医療施設と介護老人保健施設では下位尺度の興奮が高く, 介護老人福 祉施設では無為・無関心が高かった．NPIの各項目を目的変数とした重回帰分析においては，QOLD の対処困難 行動のコントロールは有意な抑制因子になっていたものが多かった．結論：NPI の各項目を目的変数とした重回 帰分析において，QOLD のいずれかの下位尺度と有意な関係がみられた，以上のことから QOL の維持向上に対 するケアがBPSD を緩和することが示唆された.

Key words 認知症高齢者, 認知症の行動 - 心理症状 (BPSD), 生活の質, 介護保険施設

(日老医誌 $2017 ； 54 ： 392-402$ )

\section{緒 言}

人口の高齢化に伴って認知症高齢者の数は増大し, 平 成 25 年 6 月に厚生労働省は認知症高齢者が 462 万人に なると推計し, さらに軽度認知障害 $(\mathrm{MCI})$ も含めると 862 万人, 高齢者の 4 人に 1 人が認知症に直面すること になる ${ }^{1)}$. 今後, ますます認知症高齢者の対策が急務と なるが, 認知症の行動 ・ 心理症状 (Behavioral and Psychological Symptoms of Dementia : BPSD) は認知症の 症状の進行に伴って介護負担が増大すると言われてい る. 特に易怒性や攻撃性, 暴言・暴力といった興奮性の 症状や幻覚・妄想などの精神症状は介護負担を著しく増
大させ，本人および介護者の QOL を大きく低下させ $る^{2}$. BPSD に対して抗精神病薬を投与した場合, 投与 後 11〜24 週で生命予後に影響することが指摘され ${ }^{3)}$, 非 薬物的介入の必要性や内服薬選択の検討の必要性が示唆 された。その結果,「BPSD に対応する向精神薬使用ガイ ドライン」(第二版 $)^{4)}$ が公表された。 いわゆる BPSD は 特にコミュニケーションの障害による孤立化, 役割や居 場所の峦失などに起因し, 認知症という疾患と個人の要 因が絡んだストレス反応と言われている5 . 特に介護老 人福祉施設や介護老人保健施設において医師は非常勤で あることから許容範囲以上の BPSD が生じた場合, BPSD に対する非薬物的アプローチであるケアスタッフ

1) 浜松医科大学

2）国立研究開発法人国立長寿医療研究センター精神診療部

3）医療法人香流会絋伝病院

4）医療法人社会大法会遠江病院

5）医療法人社団和恵会

6）同朋大学

7) 立命館大学

受付日：2017.2.4, 採用日：2017.4.25

doi: 10.3143 /geriatrics.54.392 
の対応やコミュニケーションが重要である ${ }^{4)}$ BPSDに 対するケアも含めた非薬物的アプローチの効果として は，英国の National Health Service（NHS）が実施した 認知症高齢者の焦燥管理に関するシステマティックレ ビューでは, パーソン・センタード・ケア, コミュニケー ション技術, 認知症ケアマッピング, 感覚治療活動, 音 楽療法などの有効性が報告され ( $^{6}, \mathrm{BPSD}$ に効果がある ことが明らかになった。 しかしながら, これらの非薬物 的アプローチのない状態でどのような心理的要因が BPSD と関係があるのかは明らかではない. 認知症高齢 者の BPSD は ADL 低下 ${ }^{7)}$ や転倒 ${ }^{8)}$ を引起こすことが指 摘されているが, 認知症高齢者の生活の質が BPSD に 及ぼす影響は明らかにはされていない. 本研究の目的は 介護保険施設に入所する認知症高齢者の BPSD の実態 を明らかにするとともに, 認知症高齢者の BPSD を目 的変数とした重回帰分析を行い, QOL との関係を明ら かにすることである。

\section{研究方法}

平成 25 年 9 月〜平成 27 年 10 月に介護老人福祉施設, 介護療養型医療施設, 介護老人保健施設の入居者を対象 に調査を実施した。 なお，対象者は認知症と診断された 高齢者, または認知症の診断がなくても介護保険の認知 症高齢者の日常生活自立度において II 以上と評価され ている者とした。

\section{倫理面への配慮}

対象者は認知症高齢者であることから本人の家族に対 して研究の目的・方法, プライバシーの保護, 研究発表 などについて説明を行い, 書面にて研究承諾を得た。さ らにデータは研究代表者の研究室で厳しく管理された。 なお, 本研究は浜松医科大学研究倫理審査委員会の承認 を得た。

\section{評価方法}

\section{1. 性別・年齢・疾患・BPSD に対する治療および ADL に関する情報}

担当看護師がカルテなどから, 対象者の性別・年齢, 認知症の種類, BPSD に用いられる薬剤などの情報を得
た.

\section{ADL (Katz)}

基本的な $\mathrm{ADL}$ を測定する評価指標で入浴, 更衣, 卜 イレへの移動, 移乗, 排泄コントロール, 食事における 自立の評価に関して自立 (1 点), 一部介助 (2 点), 全 面介助（3 点）の 3 段階で評価した . 得点が高いほど ADLの悪化を示す.

\section{Mini-mental State Examination (MMSE)}

認知機能のスクリーニング検査で下位尺度は時間（5 点) と場所 (5 点) の見当識, 3 つの言葉の記憶 (3 点), 注意と計算 (5 点), 3 つの言葉の想起 (3 点), 言語 (8 点), 視覚構成 (1 点) から構成され ${ }^{10)}$, 本研究では合計 点を使用した. 合計点は $0 \sim 30$ 点で 23 点以下は認知症 の疑いがあり, 得点が低下するほど認知機能の悪化を示 している.

\section{Neuropsychiatric Inventory（NPI） スコア}

BPSD に関する評価としてNPIを用いた，得点は， 妄想, 幻覚, 興奮, 抑うつ状態, 不安, 多幸, 無関心, 脱抑制, 易刺激性, 異常行動, 夜間行動, 食行動の 12 項目について 5 段階の頻度（0４４点）と４段階の重症 度（0〜3 点）の積と 6 段階の職業的負担度（0～5）で 評価 $^{11)}$, NPI スコアの点数が高いほど精神症状が強いこ とを示す。本研究では頻度と重症度の積を示した。

\section{Quality of life inventory for elderly with dementia (QOLD)}

QOLD は, Rabins らの Alzheimer's Disease Related Quality of Life (AD-QOL) ${ }^{12}$ をもとに, 山本らが日本の 文化に基づいた新しい測定項目を追加して開発した看護 師・介護士などの行動観察による認知症高齢者の QOL 尺度である ${ }^{13)}$. 質問項目は「周囲との生き生きとした交 流」8 項目,「自分らしさの表現」10 項目,「対応困難な行 動のコントロール」6 項目の 3 つの下位尺度から構成さ れ，それぞれの下位尺度の合計の割合が評価として示さ れ，高いほど良い状況を示す。

各施設で対象者の担当の看護師・介護士に対して本研 究の主旨の説明と使用する評価指標に関して 1 時間ほど の研修を実施後, 属性, ADL, QOLD やNPI に関する 評価を依頼した。同時期に認知症看護の実践と認知機能 
表 1 対象者の属性（入所施設や認知症の種類）

\begin{tabular}{|c|c|c|c|c|c|c|c|c|c|c|}
\hline & \multirow{2}{*}{\multicolumn{2}{|c|}{ 項目 }} & \multicolumn{2}{|c|}{$\begin{array}{l}\text { 介護老人 } \\
\text { 福祉施設 } \\
\end{array}$} & \multicolumn{2}{|c|}{$\begin{array}{c}\text { 介護療養型 } \\
\text { 医療施設 }\end{array}$} & \multicolumn{2}{|c|}{$\begin{array}{l}\text { 介護老人 } \\
\text { 保健施設 }\end{array}$} & \multicolumn{2}{|c|}{ 合計 } \\
\hline & & & 人数 & $\%$ \% & 人数 & $\% *$ & 人数 & $\%$ * & 人数 & $\%$ \\
\hline \multirow[t]{6}{*}{ 認知症の診断あり } & \multicolumn{2}{|c|}{ アルツハイマー型認知症 } & 94 & 47.00 & 24 & 26.37 & 98 & 43.36 & 216 & 41.78 \\
\hline & \multicolumn{2}{|c|}{ 脳血管性認知症 } & 28 & 14.00 & 15 & 16.48 & 30 & 13.27 & 73 & 14.12 \\
\hline & \multicolumn{2}{|c|}{ レビー小体型認知症 } & 2 & 1.00 & 4 & 4.40 & 4 & 1.77 & 10 & 1.93 \\
\hline & \multicolumn{2}{|c|}{ 前頭側頭型認知症 } & 3 & 1.50 & 5 & 5.49 & 4 & 1.77 & 12 & 2.32 \\
\hline & \multicolumn{2}{|c|}{ 混合型認知症 } & 31 & 15.50 & 25 & 27.47 & 9 & 3.98 & 65 & 12.57 \\
\hline & \multicolumn{2}{|c|}{ その他の認知症 } & 15 & 7.50 & 4 & 4.40 & 7 & 3.10 & 26 & 5.03 \\
\hline 認知症の診断なし & \multicolumn{2}{|c|}{ 認知症高齢者の日常生活自立度 II 以上 } & 27 & 13.50 & 14 & 15.38 & 74 & 32.74 & 115 & 22.24 \\
\hline \multicolumn{3}{|c|}{ 合計 } & 200 & 100.00 & 91 & 100.00 & 226 & 100.00 & 517 & 100.00 \\
\hline \multicolumn{2}{|c|}{ BPSD に用いられる薬剤 } & あり & 96 & 48.00 & 59 & 64.84 & 106 & 46.90 & 261 & 50.48 \\
\hline \multicolumn{2}{|c|}{ 拘縮 } & あり & 73 & 36.50 & 35 & 38.46 & 91 & 40.27 & 199 & 38.49 \\
\hline \multicolumn{2}{|l|}{ 運動器麻痺 } & あり & 35 & 17.50 & 13 & 14.29 & 72 & 31.86 & 120 & 23.21 \\
\hline \multicolumn{2}{|l|}{ 難聴 } & あり & 65 & 32.50 & 19 & 20.88 & 61 & 26.99 & 145 & 28.05 \\
\hline \multicolumn{2}{|l|}{ 失語 } & あり & 23 & 11.50 & 14 & 15.38 & 42 & 18.58 & 79 & 15.28 \\
\hline
\end{tabular}

※施設に対する割合を示す.

検査の経験のある看護師が MMSE を調査した.

統計学的解析には IBM $^{\circledR}$ SPSS ${ }^{\circledR}$ ver21 を用いて NPI の 各項目を目的変数, 年齢, ADL, MMSE, QOLDの下 位尺度を説明変数とし，重回帰分析を算出した。

\section{結 果}

\section{1. 対象者の属性}

対象者は男性 121 名（23.4\%），女性 396 名（76.6\%）の 合計 517 名であった。施設別では介護老人福祉施設 200 名 $(38.7 \%)$, 介護療養型医療施設 91 名 $(17.6 \%)$, 介護 老人保健施設 226 名 $(43.7 \%)$ であった. 平均年齢では 全体で 85.18（ $\pm 7.13 ）$ 歳であったが, 介護療養型医療 施設が最も高く $87.45( \pm 6.91)$ 歳, 次いで介護老人福 祉施設 $85.13( \pm 7.04)$ 歳, 介護老人保健施設 $82.58( \pm$ 9.04）歳であった。 入所期間に関しては全体では 28.97 ( \pm 25.69$)$ 力月, 最も長いのは介護老人福祉施設 35.18 $( \pm 24.63)$ 力月, 短いのは介護老人保健施設 23.03 ( \pm 22.54$)$ カ月であった。

表 1 に認知症の種類を示した. アルツハイマー型認知 症 216 名 $(41.78 \%)$, 脳血管性認知症 73 名 (14.12\%), レビー小体型認知症 10 名 $(1.93 \%)$, 前頭側頭型認知症 12 名 $(2.32 \%)$ であった。施設別にみると最も多かった のは, アルツハイマー型認知症の介護老人保健施設 94 名 $(47.00 \%$ ）および介護老人福祉施設 98 名 (43.36\%)
であり，介護療養型医療施設では混合型認知症 25 名 (27.47\%) であった。認知症の診断がなく，認知症高齢 者の日常生活自立度 II 以上 115 名 $(22.24 \%)$ であった。

BPSD治療に用いられる薬剂は261名（全体の $50.48 \%$ ）が内服し, 介護療養型医療施設では 59 名 (64.84\%) であった。身体機能に関して, 介護老人保健 施設では拘縮 91 名 $(40.27 \%)$, 運動器麻痺 72 名 (31.86\%), 失語 42 名 (18.58\%) と最も割合が高かった。難聴では 介護老人福祉施設が 65 名 $(32.50 \%)$ と最も割合が高かっ た。

\section{2. $A D L, M M S E, N P I, Q O L D$ の平均値}

表 2 に施設別の対象者の ADL, MMSE, NPI, QOLD の平均值を示した. ADL は介護老人保健施設が 14.50 $( \pm 3.30)$ と最も高く, MMSE は介護療養型医療施設が 10.58（土9.12）と高かった. QOLDは 3つの下位尺度 とも介護老人福祉施設が他の施設に比べて高く, 介護療 養型医療施設では最も低かった。 NPI に関しては，頻度 と重症度の積を示したが, 介護療養型医療施設と介護老 人保健施設では下位尺度の興奮が高く, それぞれ 2.88( \pm 7.96)，2.03（土3.19）であり，介護老人福祉施設では無 為・無関心が高く，1.96（土3.26）であった。

表 3 にNPIの各項目と年齢, MMSE, ADL, QOLD の相関係数を示した. 年齢と有意な相関がみられたのは, NPI の興奮, 脱抑制, 異常行動, 易刺激性・不安定であ 
表 $2 \mathrm{ADL}, \mathrm{MMSE}, \mathrm{QOLD}, \mathrm{NPI}$ の平均値と標準偏差

\begin{tabular}{|c|c|c|c|c|c|c|c|c|}
\hline \multirow{2}{*}{ 項目 } & \multicolumn{2}{|c|}{ 介護老人福祉施設 } & \multicolumn{2}{|c|}{ 介護療養型医療施設 } & \multicolumn{2}{|c|}{ 介護老人保健施設 } & \multicolumn{2}{|c|}{ 全体 } \\
\hline & 平均值 & 標準偏差 & 平均值 & 標準偏差 & 平均値 & 標準偏差 & 平均值 & 標準偏差 \\
\hline ADL（合計） & 13.58 & 3.66 & 13.77 & 4.21 & 14.50 & 3.30 & 14.02 & 3.64 \\
\hline MMSE（合計） & 9.53 & 8.30 & 10.58 & 9.12 & 8.92 & 8.68 & 9.45 & 8.62 \\
\hline \multicolumn{9}{|l|}{ QOLD } \\
\hline 周囲との生き生きとした交流 & 50.96 & 25.29 & 37.52 & 25.28 & 42.83 & 19.85 & 45.04 & 23.57 \\
\hline 自分らしさの表現 & 46.55 & 26.06 & 35.29 & 22.69 & 37.17 & 19.66 & 40.47 & 23.33 \\
\hline 対処困難行動のコントロール & 80.77 & 20.87 & 73.12 & 21.87 & 81.25 & 19.91 & 79.63 & 20.82 \\
\hline \multicolumn{9}{|l|}{ NPI（頻度 $\times$ 重症度） } \\
\hline 妄想 & 0.85 & 2.11 & 0.43 & 1.27 & 0.83 & 2.26 & 0.77 & 2.06 \\
\hline 幻覚 & 0.69 & 1.86 & 0.32 & 0.94 & 0.75 & 1.99 & 0.65 & 1.80 \\
\hline 興奮 & 1.82 & 2.84 & 2.88 & 7.96 & 2.03 & 3.19 & 2.10 & 4.33 \\
\hline うつ·不快 & 0.70 & 1.58 & 0.36 & 1.01 & 0.42 & 1.57 & 0.52 & 1.49 \\
\hline 不安 & 0.84 & 2.10 & 0.51 & 1.73 & 0.43 & 1.43 & 0.60 & 1.77 \\
\hline 多幸 ～～～～～ & 0.39 & 1.23 & 0.23 & 0.93 & 0.03 & 0.16 & 0.20 & 0.88 \\
\hline 無為·無関心 & 1.96 & 3.26 & 1.63 & 2.75 & 1.67 & 2.58 & 1.77 & 2.89 \\
\hline 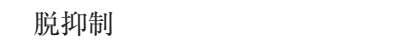 & 0.47 & 1.41 & 0.55 & 1.52 & 1.00 & 2.40 & 0.71 & 1.94 \\
\hline 易刺激性·不安定性 & 1.20 & 2.56 & 1.53 & 2.81 & 1.26 & 2.54 & 1.28 & 2.59 \\
\hline 異常行動 & 1.22 & 2.44 & 0.93 & 2.23 & 0.82 & 2.09 & 0.99 & 2.26 \\
\hline 睡眠 ～～～～～～ & 1.52 & 2.86 & 1.22 & 1.97 & 1.31 & 2.51 & 1.37 & 2.57 \\
\hline 食欲·食行動異常 & 1.62 & 3.17 & 0.80 & 2.42 & 1.09 & 2.66 & 1.24 & 2.84 \\
\hline
\end{tabular}

表 $3 \mathrm{NPI}$ の各項目と年齢, MMSE, ADL, QOLD の相関係数

\begin{tabular}{|c|c|c|c|c|c|c|c|}
\hline \multirow{2}{*}{$\begin{array}{c}\text { NPI } \\
(\text { 頻度 } \times \text { 重症度 })\end{array}$} & \multirow[b]{2}{*}{ 相関係数 } & \multirow[b]{2}{*}{ 年齢 } & \multirow[b]{2}{*}{ MMSE } & \multirow[b]{2}{*}{$\mathrm{ADL}$} & \multicolumn{3}{|c|}{ QOLD } \\
\hline & & & & & 周囲と交流 & $\begin{array}{c}\text { 自分らしさ } \\
\text { の表現 }\end{array}$ & $\begin{array}{c}\text { 対処困難行動の } \\
\text { コントロール }\end{array}$ \\
\hline \multirow[t]{2}{*}{ 妄想 } & $\mathrm{r}$ & -0.018 & 0.002 & -0.063 & 0.085 & 0.031 & -0.341 \\
\hline & $\mathrm{p}$ 值 & 0.687 & 0.970 & 0.152 & 0.054 & 0.486 & 0.000 \\
\hline \multirow[t]{2}{*}{ 幻覚 } & $\mathrm{r}$ & 0.007 & -0.062 & 0.039 & 0.040 & -0.071 & -0.260 \\
\hline & $\mathrm{p}$ 值 & 0.874 & 0.162 & 0.379 & 0.365 & 0.104 & 0.000 \\
\hline \multirow[t]{2}{*}{ 興奮 } & $\mathrm{r}$ & -0.189 & -0.160 & 0.041 & -0.136 & -0.126 & -0.447 \\
\hline & $\mathrm{p}$ 值 & 0.000 & 0.000 & 0.352 & 0.002 & 0.004 & 0.000 \\
\hline \multirow[t]{2}{*}{ うつ·不快 } & $\mathrm{r}$ & -0.022 & 0.111 & -0.102 & 0.068 & 0.111 & -0.178 \\
\hline & $\mathrm{p}$ 值 & 0.611 & 0.011 & 0.021 & 0.123 & 0.012 & 0.000 \\
\hline \multirow[t]{2}{*}{ 不安 } & $\mathrm{r}$ & -0.056 & 0.034 & -0.035 & -0.027 & 0.018 & -0.240 \\
\hline & $\mathrm{p}$ 值 & 0.204 & 0.442 & 0.422 & 0.548 & 0.681 & 0.000 \\
\hline \multirow[t]{2}{*}{ 多幸 } & $r$ & -0.043 & -0.048 & 0.020 & 0.232 & 0.032 & -0.090 \\
\hline & $\mathrm{p}$ 值 & 0.334 & 0.279 & 0.656 & 0.000 & 0.463 & 0.041 \\
\hline \multirow[t]{2}{*}{ 無為·無関心 } & $\mathrm{r}$ & 0.014 & -0.330 & 0.308 & -0.364 & -0.389 & -0.193 \\
\hline & $\mathrm{p}$ 值 & 0.748 & 0.000 & 0.000 & 0.000 & 0.000 & 0.000 \\
\hline \multirow[t]{2}{*}{ 脱抑制 } & $\mathrm{r}$ & -0.092 & -0.006 & -0.012 & 0.028 & -0.060 & -0.404 \\
\hline & $\mathrm{p}$ 值 & 0.037 & 0.888 & 0.790 & 0.523 & 0.172 & 0.000 \\
\hline \multirow{2}{*}{$\begin{array}{l}\text { 易刺激性 } \\
\text { 不安定性 }\end{array}$} & $\mathrm{r}$ & -0.143 & -0.081 & -0.006 & -0.050 & -0.068 & -0.601 \\
\hline & $\mathrm{p}$ 值 & 0.001 & 0.065 & 0.884 & 0.257 & 0.125 & 0.000 \\
\hline \multirow[t]{2}{*}{ 異常行動 } & $\mathrm{r}$ & -0.105 & -0.106 & -0.027 & 0.009 & -0.090 & -0.385 \\
\hline & $\mathrm{p}$ 值 & 0.017 & 0.016 & 0.545 & 0.831 & 0.040 & 0.000 \\
\hline \multirow[t]{2}{*}{ 睡眠 } & $\mathrm{r}$ & 0.047 & -0.145 & 0.101 & -0.082 & -0.152 & -0.322 \\
\hline & $\mathrm{p}$ 值 & 0.288 & 0.001 & 0.021 & 0.062 & 0.001 & 0.000 \\
\hline \multirow{2}{*}{$\begin{array}{l}\text { 食欲 } \\
\text { 食行動異常 }\end{array}$} & $\mathrm{r}$ & 0.043 & -0.143 & 0.121 & -0.139 & -0.171 & -0.178 \\
\hline & $\mathrm{p}$ 值 & 0.331 & 0.001 & 0.006 & 0.002 & 0.000 & 0.000 \\
\hline
\end{tabular}


り，いずれも有意な負の相関がみられた. MMSE とは 興奮, 無為 - 無関心, 異常行動, 睡眠, 食欲 - 食行動異 常が負の有意な相関, うつ・不快は正の有意な相関がみ られた. ADL とは無為・無関心, 睡眠, 食欲・食行動 異常が正の有意な相関, うつ・不快は負の有意な相関が みられた，QDLDの対処困難のコントロールとはすべ てのNPIの項目と, 負の相関が認められた. NPIの興 奮, うつ・不快, 無為・無関心, 食欲・食行動異常とす べての QOLD の項目と負の相関が認められた.

表 4 にNPI の下位尺度を目的変数とした重回帰分析 の結果を示した。ほとんどの項目において QOLD（対 処困難行動のコントロール）の $\beta$ はマイナスを示し, 有意に抑制因子になっていた。 妄想において QOLD（対 処困難行動のコントロール）が有意に抑制因子になって おり，介護老人保健施設ではそれに加えてQOLD（自 分らしさの表現）で有意に抑制因子になっていた，幻覚 において施設全体では，QOLD（周囲との生き生きとし た交流）は有意な促進因子に, QOLD（対処困難行動の コントロール), QOLD（自分らしさの表現）は有意に 抑制因子になっていた。興奮において年齢, MMSE, QOLD（対処困難行動のコントロール）は有意に抑制因 子になっていた。

\section{考 察}

\section{施設別の特徵}

本研究は介護老人福祉施設, 介護老人保健施設, 介護 療養型医療施設の 3 施設のそれぞれにおける認知症高齢 者の BPSDの実態を明らかにするとともに，NPIを目 的変数として年齢, ADL, MMSE, QOLDの下位尺度 との関係を明らかにした，対象者の平均年齢は介護老人 保健施設, ADL は介護老人保健施設, MMSE は介護療 養型医療施設が高いなどそれぞれの傾向がみられた．介 護老人福祉施設は「終のすみか」とも言われ, 近年, 看 取りなどエンド・オブ・ライフ・ケアを重視している. 介護老人保健施設は自宅と病院を結ぶ中間施設という位 置づけとなっている.介護療養型医療施設は長期療養が 必要な要介護高齿者が入院する医療施設である. 介護老 人福祉施設の対象者は ADLの合計が最も低かったが, QOLD の下位尺度 3 項目ともに他の施設よりも高かっ た. 一方, 介護老人保健施設では中間施設を目指してリ ハビリテーションなどが重視され, ADL は良好で BPSD
は少ない傾向にあった，介護療養型医療施設では身体治 療を目的で入院していることから QOLD の平均值は最 も低くなったと考えられ，これらの特徵は施設の特徵か らの相違であることが推察される.

\section{BPSD と年齢・MMSE との関係}

年齢が進むにつれ，BPSD は増加すると言われてい る ${ }^{14)}$ が, 年齢と NPIの興奮, 脱抑制, 異常行動でいずれ も有意な負の相関がみられ，年齢が低い認知症高齢者ほ ど活動性 BPSD である興奮, 脱抑制, 異常行動を示し たことが明らかになった，高橋は BPSDの原因は孤立 して不安な認知症高齢者の急性ストレス反応であること を指摘 ${ }^{15}$ しており，年齢が低いと ADL が高いことから 急性のストレス反応を活動性の BPSD で示すことが考 えられる. BPSD は認知症が重度化するに伴い出現する と報告 ${ }^{16)}$ れ, 本研究では非活動性 BPSD であるうつ・ 不快感と有意な正の相関が認められた。 しかし, MMSE と活動性 BPSD である興奮, 異常行動, 易刺激性・不 安定, 食欲・食行動異常では負の有意な相関が認められ た。これらの結果から MMSE が良好な場合は非活動性 のうつ・不快感などが, MMSEの悪化した場合は, 活 動性の BPSD として, 高橋のストレス反応を表出して いる可能性が示唆された。 キットウッドは認知症高齢者 の $1 / 3$ はうつ症状を示し, 認知症の悪化に伴いその人ら

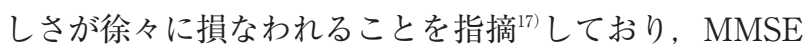
の比較的良好な者は非活動性のうつ・不快感が表れ, BPSD 悪化に伴って活動性 BPSD を示しやすいことが 考えられる. MMSEが悪化するほど ADLも有意に低 下しており, ADLの悪化と無為・無関心, 睡眠, 食欲・ 食行動異常が正の有意な相関, うつ・不快は負の有意な 相関がみられた。要介護認定を受けた認知症者の BPSD は認知機能障害に伴う日常生活動作評価票 (ADL-cog) と有意な関係があり ${ }^{18)}$, BPSD は ADLの影響が大きい という報告もあるが, 非活動性の BPSD は活動性の BPSD よりも見落とされがちな傾向にあると言える。

\section{BPSD とADL の関係}

NPI の下位尺度を目的変数とした重回帰分析では, ADL は標準化係数（ $\beta$ ）がマイナスと抑制因子として認 められていた. 唯一介護老人保健施設の無為・無関心で $\mathrm{ADL}$ が有意な促進因子（ $\beta$ がプラス）であった．無為・ 無関心は周囲の世界に関心を失っている状況であり，意 
表 4 NPI の下位尺度を目的変数とした重回帰分析

\begin{tabular}{|c|c|c|c|c|c|c|c|c|c|}
\hline \multirow{2}{*}{$\mathrm{N}$} & \multirow[b]{2}{*}{ 説明変数 } & \multicolumn{2}{|c|}{$\begin{array}{l}\text { 介護老人 } \\
\text { 福祉施設 }\end{array}$} & \multicolumn{2}{|c|}{$\begin{array}{c}\text { 介護療養型 } \\
\text { 医療施設 }\end{array}$} & \multicolumn{2}{|c|}{$\begin{array}{l}\text { 介護老人 } \\
\text { 保健施設 }\end{array}$} & \multicolumn{2}{|c|}{ 全体 } \\
\hline & & $\begin{array}{l}\text { 標潐化 } \\
\text { 係数 } \\
(\beta)\end{array}$ & $\mathrm{p}$ 值 & $\begin{array}{l}\text { 標準化 } \\
\text { 係数 } \\
(\beta)\end{array}$ & $\mathrm{p}$ 值 & $\begin{array}{l}\text { 標潐化 } \\
\text { 係数 } \\
(\beta)\end{array}$ & $\mathrm{p}$ 值 & $\begin{array}{c}\text { 標潐化 } \\
\text { 係数 } \\
(\beta)\end{array}$ & $\mathrm{p}$ 值 \\
\hline \multirow[t]{8}{*}{ 妄想 } & 年齢 & -0.007 & 0.918 & -0.055 & 0.599 & 0.051 & 0.422 & 0.054 & 0.203 \\
\hline & $\mathrm{ADL}^{1)}$ & -0.015 & 0.880 & -0.135 & 0.331 & -0.108 & 0.190 & -0.07 & 0.220 \\
\hline & $\mathrm{MMSE}^{2)}$ & -0.103 & 0.360 & -0.210 & 0.184 & 0.151 & 0.086 & 0.013 & 0.835 \\
\hline & QOLD 周囲との生き生きとした交流 & 0.056 & 0.583 & 0.022 & 0.872 & 0.140 & 0.080 & 0.122 & 0.037 \\
\hline & QOLD 自分らしさの表現 & 0.108 & 0.442 & 0.318 & 0.096 & -0.278 & 0.008 & -0.077 & 0.318 \\
\hline & QOLD 対処困難行動のコントロール & -0.337 & 0.000 & -0.356 & 0.001 & -0.388 & 0.000 & -0.355 & 0.000 \\
\hline & $\mathrm{R}$ & & 0.268 & & 0.397 & & 0.442 & & 0.364 \\
\hline & $\mathrm{R}^{2}$ & & 0.072 & & 0.158 & & 0.195 & & 0.133 \\
\hline \multirow[t]{8}{*}{ 幻覚 } & 年齢 & -0.042 & 0.562 & -0.068 & 0.536 & 0.097 & 0.121 & 0.061 & 0.162 \\
\hline & $\mathrm{ADL}^{1)}$ & 0.147 & 0.141 & 0.036 & 0.806 & -0.123 & 0.133 & -0.008 & 0.896 \\
\hline & $\mathrm{MMSE}^{2)}$ & 0.007 & 0.953 & -0.213 & 0.201 & 0.141 & 0.108 & 0.045 & 0.478 \\
\hline & QOLD 周囲との生き生きとした交流 & 0.219 & 0.039 & 0.086 & 0.551 & 0.101 & 0.202 & 0.174 & 0.004 \\
\hline & QOLD 自分らしさの表現 & -0.096 & 0.506 & 0.289 & 0.150 & -0.364 & 0.001 & -0.206 & 0.010 \\
\hline & QOLD 対処困難行動のコントロール & -0.166 & 0.024 & -0.260 & 0.015 & -0.365 & 0.000 & -0.268 & 0.000 \\
\hline & $\mathrm{R}$ & & 0.268 & & 0.397 & & 0.442 & & 0.298 \\
\hline & $\mathrm{R}^{2}$ & & 0.072 & & 0.158 & & 0.195 & & 0.089 \\
\hline \multirow[t]{8}{*}{ 興奮 } & 年齢 & -0.044 & 0.465 & -0.291 & 0.007 & -0.044 & 0.386 & -0.112 & 0.005 \\
\hline & $\mathrm{ADL}^{1)}$ & 0.013 & 0.873 & -0.153 & 0.279 & 0.009 & 0.897 & -0.067 & 0.216 \\
\hline & $\mathrm{MMSE}^{2)}$ & -0.130 & 0.179 & -0.433 & 0.008 & 0.016 & 0.818 & -0.138 & 0.019 \\
\hline & QOLD 周囲との生き生きとした交流 & -0.144 & 0.104 & -0.249 & 0.079 & 0.005 & 0.937 & -0.108 & 0.050 \\
\hline & QOLD 自分らしさの表現 & 0.074 & 0.540 & 0.270 & 0.164 & -0.051 & 0.545 & 0.041 & 0.570 \\
\hline & QOLD 対処困難行動のコントロール & -0.531 & 0.000 & -0.164 & 0.109 & -0.681 & 0.000 & -0.406 & 0.000 \\
\hline & $\mathrm{R}$ & & 0.593 & & 0.456 & & 0.691 & & 0.481 \\
\hline & $\mathrm{R}^{2}$ & & 0.352 & & 0.208 & & 0.477 & & 0.231 \\
\hline \multirow[t]{8}{*}{ 抑うつ } & 年齢 & -0.031 & 0.666 & -0.181 & 0.101 & 0.040 & 0.552 & 0.025 & 0.578 \\
\hline & $\mathrm{ADL}^{1)}$ & -0.017 & 0.864 & 0.169 & 0.247 & -0.069 & 0.435 & -0.014 & 0.809 \\
\hline & $\mathrm{MMSE}^{2)}$ & 0.060 & 0.609 & -0.180 & 0.280 & 0.222 & 0.019 & 0.094 & 0.149 \\
\hline & QOLD 周囲との生き生きとした交流 & -0.055 & 0.605 & -0.234 & 0.110 & 0.005 & 0.952 & -0.012 & 0.841 \\
\hline & QOLD 自分らしさの表現 & 0.118 & 0.416 & 0.598 & 0.004 & -0.133 & 0.237 & 0.063 & 0.435 \\
\hline & QOLD 対処困難行動のコントロール & -0.220 & 0.003 & -0.167 & 0.116 & -0.191 & 0.005 & -0.202 & 0.000 \\
\hline & $\mathrm{R}$ & & 0.253 & & 0.390 & & 0.263 & & 0.231 \\
\hline & $\mathrm{R}^{2}$ & & 0.064 & & 0.152 & & 0.069 & & 0.053 \\
\hline \multirow[t]{8}{*}{ 不安 } & 年齢 & -0.066 & 0.361 & 0.020 & 0.850 & -0.017 & 0.797 & 0.001 & 0.987 \\
\hline & $\mathrm{ADL}^{1)}$ & -0.048 & 0.630 & -0.021 & 0.886 & 0.074 & 0.399 & 0.002 & 0.978 \\
\hline & $\mathrm{MMSE}^{2)}$ & -0.006 & 0.955 & 0.058 & 0.722 & 0.227 & 0.016 & 0.07 & 0.282 \\
\hline & QOLD 周囲との生き生きとした交流 & -0.067 & 0.525 & -0.304 & 0.036 & -0.036 & 0.673 & -0.075 & 0.216 \\
\hline & QOLD 自分らしさの表現 & -0.009 & 0.950 & 0.216 & 0.274 & -0.011 & 0.924 & 0.046 & 0.563 \\
\hline & QOLD 対処困難行動のコントロール & -0.240 & 0.001 & -0.383 & 0.000 & -0.220 & 0.001 & -0.251 & 0.000 \\
\hline & $\mathrm{R}$ & & 0.271 & & 0.421 & & 0.264 & & 0.256 \\
\hline & $\mathrm{R}^{2}$ & & 0.073 & & 0.177 & & 0.070 & & 0.065 \\
\hline
\end{tabular}




\begin{tabular}{|c|c|c|c|c|c|c|c|c|c|}
\hline \multirow[b]{2}{*}{ NPI } & \multirow[b]{2}{*}{ 説明変数 } & \multicolumn{2}{|c|}{$\begin{array}{l}\text { 介護老人 } \\
\text { 福祉施設 }\end{array}$} & \multicolumn{2}{|c|}{$\begin{array}{c}\text { 介護療養型 } \\
\text { 医療施設 }\end{array}$} & \multicolumn{2}{|c|}{$\begin{array}{l}\text { 介護老人 } \\
\text { 保健施設 }\end{array}$} & \multicolumn{2}{|c|}{ 全体 } \\
\hline & & $\begin{array}{l}\text { 標潐化 } \\
\text { 係数 } \\
(\beta)\end{array}$ & $\mathrm{p}$ 值 & $\begin{array}{l}\text { 標潐化 } \\
\text { 係数 } \\
(\beta)\end{array}$ & $\mathrm{p}$ 值 & $\begin{array}{l}\text { 標潐化 } \\
\text { 係数 } \\
(\beta)\end{array}$ & $\mathrm{p}$ 值 & $\begin{array}{c}\text { 標準化 } \\
\text { 係数 } \\
(\beta)\end{array}$ & $\mathrm{p}$ 值 \\
\hline \multirow[t]{8}{*}{ 多幸 } & 年齢 & 0.034 & 0.622 & -0.300 & 0.005 & 0.011 & 0.870 & -0.047 & 0.281 \\
\hline & $\mathrm{ADL}^{1)}$ & 0.012 & 0.896 & 0.218 & 0.122 & -0.037 & 0.675 & 0.012 & 0.831 \\
\hline & $\mathrm{MMSE}^{2)}$ & -0.081 & 0.460 & -0.128 & 0.421 & 0.152 & 0.110 & -0.078 & 0.219 \\
\hline & QOLD 周囲との生き生きとした交流 & 0.554 & 0.000 & 0.321 & 0.023 & 0.194 & 0.025 & 0.402 & 0.000 \\
\hline & QOLD 自分らしさの表現 & -0.378 & 0.006 & 0.128 & 0.506 & -0.221 & 0.052 & -0.18 & 0.023 \\
\hline & QOLD 対処困難行動のコントロール & -0.097 & 0.162 & 0.071 & 0.484 & -0.123 & 0.071 & -0.073 & 0.093 \\
\hline & $\mathrm{R}$ & & 0.404 & & 0.470 & & 0.222 & & 0.316 \\
\hline & $\mathrm{R}^{2}$ & & 0.164 & & 0.221 & & 0.049 & & 0.100 \\
\hline \multirow[t]{8}{*}{ 無為·無関心 } & 年齢 & 0.059 & 0.333 & 0.001 & 0.996 & 0.012 & 0.854 & 0.046 & 0.261 \\
\hline & $\mathrm{ADL}^{1)}$ & 0.100 & 0.226 & -0.101 & 0.489 & 0.217 & 0.010 & 0.103 & 0.061 \\
\hline & $\mathrm{MMSE}^{2)}$ & -0.085 & 0.378 & -0.135 & 0.417 & 0.007 & 0.939 & -0.07 & 0.237 \\
\hline & QOLD 周囲との生き生きとした交流 & -0.266 & 0.003 & -0.203 & 0.164 & -0.148 & 0.069 & -0.207 & 0.000 \\
\hline & QOLD 自分らしさの表現 & -0.200 & 0.098 & -0.119 & 0.551 & -0.030 & 0.778 & -0.116 & 0.119 \\
\hline & QOLD 対処困難行動のコントロール & -0.151 & 0.014 & -0.187 & 0.079 & -0.213 & 0.001 & -0.169 & 0.000 \\
\hline & $\mathrm{R}$ & & 0.596 & & 0.388 & & 0.389 & & 0.457 \\
\hline & $\mathrm{R}^{2}$ & & 0.356 & & 0.150 & & 0.152 & & 0.208 \\
\hline \multirow[t]{8}{*}{ 脱抑制 } & 年齢 & -0.026 & 0.692 & 0.047 & 0.669 & -0.051 & 0.392 & 0 & 0.991 \\
\hline & $\mathrm{ADL}^{1)}$ & 0.014 & 0.878 & -0.206 & 0.162 & -0.032 & 0.678 & -0.035 & 0.532 \\
\hline & MMSE $^{2)}$ & 0.171 & 0.107 & -0.154 & 0.360 & 0.181 & 0.030 & 0.134 & 0.027 \\
\hline & QOLD 周囲との生き生きとした交流 & 0.018 & 0.851 & 0.202 & 0.168 & 0.208 & 0.006 & 0.149 & 0.009 \\
\hline & QOLD 自分らしさの表現 & -0.138 & 0.298 & 0.059 & 0.770 & -0.344 & 0.001 & -0.242 & 0.001 \\
\hline & QOLD 対処困難行動のコントロール & -0.476 & 0.000 & -0.232 & 0.031 & -0.479 & 0.000 & -0.410 & 0.000 \\
\hline & $\mathrm{R}$ & & 0.477 & & 0.375 & & 0.524 & & 0.429 \\
\hline & $\mathrm{R}^{2}$ & & 0.228 & & 0.141 & & 0.275 & & 0.184 \\
\hline \multirow[t]{8}{*}{ 易刺激性・不安定性 } & 年齢 & 0.005 & 0.933 & -0.071 & 0.422 & -0.029 & 0.599 & -0.022 & 0.545 \\
\hline & $\mathrm{ADL}^{1)}$ & -0.020 & 0.812 & -0.148 & 0.206 & -0.039 & 0.591 & -0.052 & 0.294 \\
\hline & $\mathrm{MMSE}^{2)}$ & -0.059 & 0.546 & -0.051 & 0.701 & 0.061 & 0.432 & -0.003 & 0.955 \\
\hline & QOLD 周囲との生き生きとした交流 & -0.039 & 0.660 & 0.000 & 0.999 & -0.017 & 0.805 & -0.014 & 0.783 \\
\hline & QOLD 自分らしさの表現 & -0.012 & 0.925 & 0.009 & 0.955 & -0.051 & 0.575 & -0.034 & 0.605 \\
\hline & QOLD 対処困難行動のコントロール & -0.558 & 0.000 & -0.648 & 0.000 & -0.602 & 0.000 & -0.594 & 0.000 \\
\hline & $\mathrm{R}$ & & 0.596 & & 0.388 & & 0.389 & & 0.604 \\
\hline & $\mathrm{R}^{2}$ & & 0.356 & & 0.150 & & 0.152 & & 0.364 \\
\hline \multirow[t]{8}{*}{ 異常行動 } & 年齢 & -0.096 & 0.163 & -0.087 & 0.413 & -0.030 & 0.627 & -0.032 & 0.444 \\
\hline & $\mathrm{ADL}^{1)}$ & -0.139 & 0.137 & -0.242 & 0.089 & -0.129 & 0.108 & -0.159 & 0.005 \\
\hline & $\mathrm{MMSE}^{2)}$ & -0.177 & 0.107 & -0.264 & 0.105 & 0.125 & 0.144 & -0.077 & 0.203 \\
\hline & QOLD 周囲との生き生きとした交流 & 0.198 & 0.047 & -0.020 & 0.890 & 0.100 & 0.198 & 0.144 & 0.012 \\
\hline & QOLD 自分らしさの表現 & -0.190 & 0.164 & -0.026 & 0.895 & -0.301 & 0.004 & -0.205 & 0.007 \\
\hline & QOLD 対処困難行動のコントロール & -0.297 & 0.000 & -0.355 & 0.001 & -0.426 & 0.000 & -0.361 & 0.000 \\
\hline & $\mathrm{R}$ & & 0.420 & & 0.451 & & 0.474 & & 0.418 \\
\hline & $\mathrm{R}^{2}$ & & 0.177 & & 0.203 & & 0.224 & & 0.174 \\
\hline
\end{tabular}




\begin{tabular}{|c|c|c|c|c|c|c|c|c|c|}
\hline \multirow[b]{2}{*}{ NPI } & \multirow[b]{2}{*}{ 説明変数 } & \multicolumn{2}{|c|}{$\begin{array}{l}\text { 介護老人 } \\
\text { 福祉施設 }\end{array}$} & \multicolumn{2}{|c|}{$\begin{array}{c}\text { 介護療養型 } \\
\text { 医療施設 }\end{array}$} & \multicolumn{2}{|c|}{$\begin{array}{l}\text { 介護老人 } \\
\text { 保健施設 }\end{array}$} & \multicolumn{2}{|c|}{ 全体 } \\
\hline & & $\begin{array}{l}\text { 標潐化 } \\
\text { 係数 } \\
(\beta)\end{array}$ & $\mathrm{p}$ 值 & $\begin{array}{l}\text { 標潐化 } \\
\text { 倸数 } \\
(\beta)\end{array}$ & $\mathrm{p}$ 值 & $\begin{array}{c}\text { 標準化 } \\
\text { 係数 } \\
(\beta)\end{array}$ & $\mathrm{p}$ 值 & $\begin{array}{c}\text { 標潐化 } \\
\text { 係数 } \\
(\beta) \\
\end{array}$ & $\mathrm{p}$ 值 \\
\hline \multirow[t]{8}{*}{ 睡眠 } & 年齢 & 0.127 & 0.074 & 0.015 & 0.892 & 0.077 & 0.220 & 0.113 & 0.008 \\
\hline & $\mathrm{ADL}^{1)}$ & -0.046 & 0.631 & 0.093 & 0.534 & 0.042 & 0.607 & 0.006 & 0.915 \\
\hline & $\mathrm{MMSE}^{2)}$ & -0.035 & 0.754 & -0.142 & 0.405 & 0.113 & 0.195 & -0.001 & 0.983 \\
\hline & QOLD 周囲との生き生きとした交流 & 0.042 & 0.682 & 0.025 & 0.868 & 0.002 & 0.981 & 0.034 & 0.567 \\
\hline & QOLD 自分らしさの表現 & -0.189 & 0.180 & -0.031 & 0.878 & -0.158 & 0.130 & -0.143 & 0.065 \\
\hline & QOLD 対処困難行動のコントロール & -0.297 & 0.000 & -0.211 & 0.054 & -0.423 & 0.000 & -0.332 & 0.000 \\
\hline & $\mathrm{R}$ & & 0.349 & & 0.330 & & 0.442 & & 0.363 \\
\hline & $\mathrm{R}^{2}$ & & 0.122 & & 0.109 & & 0.196 & & 0.132 \\
\hline \multirow[t]{8}{*}{ 食欲/食行動異常 } & 年齢 & -0.015 & 0.833 & 0.220 & 0.042 & 0.013 & 0.846 & 0.081 & 0.069 \\
\hline & $\mathrm{ADL}^{1)}$ & 0.022 & 0.821 & -0.006 & 0.969 & 0.041 & 0.640 & 0.023 & 0.695 \\
\hline & $\mathrm{MMSE}^{2)}$ & 0.005 & 0.968 & 0.008 & 0.958 & 0.074 & 0.428 & -0.004 & 0.947 \\
\hline & QOLD 周囲との生き生きとした交流 & -0.045 & 0.671 & -0.325 & 0.023 & 0.033 & 0.697 & -0.05 & 0.413 \\
\hline & QOLD 自分らしさの表現 & -0.153 & 0.291 & 0.011 & 0.957 & -0.196 & 0.081 & -0.103 & 0.199 \\
\hline & QOLD 対処困難行動のコントロール & -0.163 & 0.027 & -0.249 & 0.017 & -0.207 & 0.002 & -0.181 & 0.000 \\
\hline & $\mathrm{R}$ & & 0.271 & & 0.440 & & 0.266 & & 0.252 \\
\hline & $\mathrm{R}^{2}$ & & 0.074 & & 0.193 & & 0.071 & & 0.064 \\
\hline
\end{tabular}

\footnotetext{
1) KazADL の合計点

2) Mini-mental State Examination (MMSE) の合計点
}

欲の低下によって生じやすい. ADL が比較的良好でも 周囲から孤立している状況が伺える. 介護老人保健施設 では，ADLが良好な高齢者に比し，ADL が低下してい る高齢者ほど ADL 介助の際にスタッフがコミュニケー ションを行っている状況が伺え, 近年の介護スタッフ不 足などの影響が示唆された。比較的 ADL が良好な高齢 者の支援体制などを検討する必要があろう。

\section{BPSD と自分らしさの表現（QOLD）の関係}

BPSD の中でも異常行動は, ADL， QOLDの自分ら しさの表現や対処困難行動のコントロールが抑制因子, 周囲との生き生きとした交流は促進因子であった，NPI の幻覚や異常行動などは，QOLDの自分らしさの表現, 対処困難行動のコントロールの低下などが異常行動を引 き起こしている可能性が示唆された。 キットゥッドは, パーソン・センタード・ケアはパーソンフッド (一人の 人として周囲に受け入れられ, 尊重されること) を維持・ 向上すること ${ }^{19}$ であり, 特別な介入のない通常のケアに おいてもパーソンフッドの阻害など心理的ニーズが満た されないことがBPSD につながることを指摘している. 異常行動などに扔ける自分らしさの表現の有意な抑制因
子としての関係, パーソンフッドの欠如から自分らしさ が表現できず幻覚や異常行動を引き起こした可能性が示 唆された。ささらに異常行動だけではなく、多幸や脱抑制 ではQOLDの周囲との生き生きとした交流が有意な促 進因子であるが，他の高齢者とのコミュニケーションが 活発に行われる状況で多幸や脱抑制などの BPSD を引 き起こしている可能性が示唆された.

介護老人保健施設で NPI のすべての項目で QOLD の 周囲との生き生きとした交流, 対処困難行動のコント ロールは抑制因子となり, 特に妄想, 幻覚, 脱抑制では 有意な抑制因子であった。 介護老人保健施設は在宅復帰 を目的としたリハビリテーション目的の施設でもある が，多岐にわたる BPSD が頻繁に出現していることも 報告 ${ }^{20)}$ され, 本研究でも妄想や興奮など活動型の BPSD が最も多かった。これらの状況から施設の中でパーソン フッドが適切に維持されていない状況が BPSD の悪化 に最も影響している状況が伺えた。 介護療養型医療施設 は医療処置や身体治療なども行われる治療の場である が，自分らしさの表現が促進因子となり，特に抑うつを 有意に促進していたことは MMSE が最も高かったなど の影響が推察される。 


\section{BPSD と対処困難行動のコントロール（QOLD）の関係}

NPI の各項目を目的変数とした重回㷌分析では QOLD の下位尺度の中の対処困難行動のコントロール が抑制因子となっており，BPSD に影響を与えている可 能性が示唆された。全体の対象者重回帰分析の対処困難 行動のコントロールでは最も BPSDの影響がみられる が，全対象者の中で NPI では多幸以外有意な抑制因子 となっている。高橋の指摘する急性ストレスに対するコ ントロールを評価する項目であり，BPSD に影響を与え ている. Hall は認知症高齢者ではストレス閾值の低下

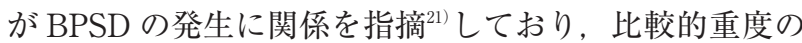
認知症高齢者を含む本研究の対象者に対処困難行動のコ ントロールを向上させることは困難と言える。

本研究では認知症高齢者の BPSD は年齢, ADL, 認 知機能をコントロールしても周囲との生き生きとした交 流, 自分らしさの表現, 対処困難行動のコントロールな どのいずれかの項目と有意な関係があり，QOL に関連 するケアや人間関係など心理社会的な要因の影響を受け ていることが示唆された。著者らの以前の研究において も QOL に対してコミュニケーションを試みても誰から も反応がない状態は QOL の有意な低下が認められてお $り^{19)}$, 認知症高齢者にとって他者との交流は重要な要因 となっている，以上の結果から介護保険施設における認 知症高齢者の $\mathrm{QOL}$ を高める要因として, 周囲との生き 生きとした交流, 自分らしさの表現, 対処困難行動のコ ントロールが BPSD に影響を与えていることが明らか になったＢPSDに対しては抗精神病薬ではなく，ケア スタッフの認知症高齢者のパーソン・センタード・ケア やコミュニケーションの技術，感覚を用いたケアなどの メタアナリシスの効果吕も認められており, 認知症ケア マッピングを用いたパーソン・センタード・ケアのノル ウェイの多施設ランダム比較試験による有意な改善の効 果 ${ }^{22)}$ からもケアスタッフ個々の対応ではなく, 施設全体 の組織的な取り組みが必要とされる.

本研究の限界として, 本研究の QOLD の評価者と NPI の評価者が，担当のケアスタッフと同一であるためにバ イアスがかかっている可能性がある. 今後さらに, BPSD とケアとの関係，介入方法を検討していきたい.

本研究は平成 25 年 27 年度長寿医療研究開発費「介 護施設, 一般病院における BPSD 初期対応の効果検証 に関する研究」(主任研究者 : 服部英幸) の研究の一部を 使用した。
本研究にご理解・ご協力頂きました対象者とそのご家 族の皆様，各施設の管理者およびスタッフの皆様に深く 感謝申し上げます。

\section{文献}

1）厚生労働省：認知症施策推進総合戦略～認知症高齢者等 にやさしい地域づくりに向けて〜（新オレンジプラン） について. http://www.mhlw.go.jp/file/04-Houdouhapp you-12304500-Roukenkyoku-Ninchishougyakutaiboushit aisakusuishinshitsu/01_1.pdf. (平成 27 年 2 月 11 日).

2）福田耕嗣，服部英幸：認知症治療の最前線一包括的ケア を踏まえた新しい治療戦略一非薬物療法と啓発活動 「BPSD 初期対応ガイドライン」と期待される効果. Geriatric Medicine 2013;51 (19):27-30.

3) 新井平伊 :【認知症の診断・臨床・治療とケア, 認知症 の人の Well-being】 BPSD J-CATIA. 老年精神医学雑誌 2016; 27: 152-156.

4）認知症に対するかかりつけ医の向精神薬使用の適正化に 関する調查研究班：かかりつけ医のための BPSD に対 応する向精神薬使用ガイドライン (第二版). https://w ww.jpn-geriat-soc.or.jp/info/topics/pdf/20160418_01_01. pdf

5）高橋幸男：【認知症医療の諸相】精神科における認知症 医療の課題と展望 認知症の人のメンタルヘルスと地域 生活支援. 老年精神医学雑誌 2014; 25 (7): 731-737.

6) Livingston G, Kelly L, Lewis-Holmes E, Baio G, Morris S, Patel N, et al.: Non-pharmacological interventions for agitation in dementia: systematic review of randomised controlled trials. Br J Psychiatry 2014; 205 (6): 436-442.

7) Tunis SL, Edell WS, Adams BE, Kennedy JS: Characterizing behavioral and psychological symptoms of dementia (BPSD) among geropsychiatric inpatients. J Am Med Dir Assoc 2002; 3 (3): 146-151.

8) Härlein J, Dassen T, Halfens RJ, Heinze C: Fall risk factors in older people with dementia or cognitive impairment: a systematic review. J Adv Nurs 2009; 65 (5): 922933.

9）伊藤利之，鎌倉矩子：ADL とその周辺 評価・指導・介 護の実際, 医学書院, 東京, 1994.

10) Folstein MF, Folstein SE, McHugh PR: Mini-mental State; Practical method for grading the cognitive state for the clinician. Journal of Psychiatric Research 1975; 12: 189-198.

11) Cummings JL, Mega M, Gray K, Rosenberg-Thompson S, Carusi DA, Gornbein J: The Neuropsychiatric Inventory: comprehensive assessment of psychopathology in dementia. Neurology 1994; 144 (12): 2308-2314.

12) Rabins PV, Kasper JD: Measuring quality of life in dementia: conceptual and practical issues. Alzheimer Dis 
Assoc Disord 1997; 11 (S6): 100-104.

13) Yamamoto-Mitani N, Abe T, Okita Y, Hayashi K, Sugishita C, Katayama K: The impact of subjects/respondent characteristics on a proxy-rated quality of life instrument for the Japanese elderly with dementia. Quality of life Research 2004; 13: 845-855.

14）長屋正博: 介護施設での BPSD 頻度と管理. BPSD 初期 対応ガイドライン (服部英幸編), ライフサイエンス, 東京, 2012, p8-11.

15）高橋幸男 :【認知症の人の認知機能障害, 生活障害, 行 動 - 心理症状の構造】認知症の人の認知機能障害, 生活 障害, BPSD（行動 - 心理症状）の心理社会的構造. 精 神医学 2016; 58 (11): 897-903.

16）鈴木優喜子, 長澤 明, 小林隆司：認知症治療病棟にお けるアルッハイマー病患者の認知症重症度と行動 - 心理 症状の関連. 日本作業療法研究学会雑誌 2016; 19 (1): $1-6$.

17）トム・キットゥッド編：（高橋誠一訳 : 認知症のパーソ ンセンタードケア一新しいケアの文化へ, 筒井書房, 東 京, 2005.

18）半田幸子, 今井幸充 : 認知症者の要介護度と ADL, BPSD ならびに認知症高齢者の日常生活自立度との関連. 老年
精神医学雑誌 2016;27 (6): 667-674.

19）鈴木みずえ, 水野 裕, Brooker D, 住垣千恵子, 坂本 凉子, 内田敦子ほか：Quality of life 評価手法としての 日本語版認知症ケアマッピング (Dementia Care Mapping:DCM) の検討 Well-being and Ill-being Value （WIB 值）に関する信頼性・妥当性. 日老医誌 2008; 45 (1): 68-76.

20）田中志子, 山口晴保, 中間浩一, 西千亜紀, 牧 陽子, 斉藤正身ほか：介護老人保健施設における認知症の実態 と対応 日本リハビリテーション病院・施設協会認知症 対策検討委員会の調查. 地域リハビリテーション 2014; 9 (8): 656-660.

21) Hall GR, Buckwalter KC: Progressively lowered stress threshold: a conceptual model for care of adults with Alzheimer's disease. Arch Psychiatr Nurs 1987; 1 (6): 399406.

22) Rokstad AM, Røsvik J, Kirkevold Ø, Selbaek G, Saltyte Benth J, Engedal K: The effect of person-centred dementia care to prevent agitation and other neuropsychiatric symptoms and enhance quality of life in nursing home patients: a 10-month randomized controlled trial. Dement Geriatr Cogn Disord 2013; 36 (5-6): 340-353. 


\section{The effects of quality of life on behavioral and psychological symptoms in elderly people with dementia residing at long-term care facilities}

Mizue Suzuki1 ${ }^{1}$, Hideyuki Hattori' ${ }^{2}$, Koji Fukuda ${ }^{3}$, Hajime Ooshiro ${ }^{4)}$, Takayuki Saruhara ${ }^{5)}$, Yoshie Furuta ${ }^{1}$,

Kunihiko Abe $^{6)}$ and Masao Kanamori ${ }^{7)}$

\section{Abstract}

Purpose: The purpose of the present study was to clarify how quality of life (QOL) affects the behavioral and psychological symptoms of dementia (BPSDs) among elderly individuals with dementia within long-term care facilities (e.g., long-term healthcare facilities, sanatorium-type medical facilities, and special nursing homes for the elderly).

Methods: Elderly individuals with dementia were evaluated to determine their activities of daily living (ADL; Katz), Mini-mental State Examination (MMSE), Neuropsychiatric Inventory (NPI), and Quality of life inventory for the elderly with dementia (QOLD) scores.

Results: The subjects were recruited from intermediate welfare facilities ( $\mathrm{n}=226,43.7 \%$ ), hospitals with supportive care ( $\mathrm{n}=91$, $17.6 \%$ ), and intermediate care facilities $(\mathrm{n}=200,38.7 \%)$. The mean age of the subjects was $85.18 \pm 7.13$ years. The NPI scores revealed that Agitation/Aggression was high among subjects who resided in healthcare health facilities and sanatorium-type medical facilities, while Apathy/Indifference was high in those who resided in special nursing homes. Additionally, a multiple regression analysis found that most of the NPI items, when set as independent variables, displayed a significant association with the same subscale of the QOLD.

Conclusion: When each item of the NPI was set as a dependent variable in a multiple regression analysis, the scores were significantly related to both subscales of the QOLD. It is suggested that QOL should be maintained or improved in an effort to reduce the incidence of the associated BPSDs in long-term care facilities.

Key words: Elderly people with dementia, Behavioral and psychological symptoms (BPSD), Quality of life, Long-term care facilities

(Nippon Ronen Igakkai Zasshi 2017; 54: 392-402)

1) Hamamatsu University

2) National Center for Geriatrics \& Gerontology

3) Kojin Hospital

4) Totomi Hospital

5) Medical Corporation Wakeikai Hospital

6) Doho University

7) Ritsumeikan University 